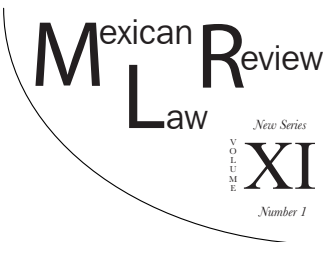

\title{
THE RIGHT TO SELF-DETERMINATION OF PEOPLES: NOTES ON ITS COMPATIBILITY WITH THREE MODELS OF GLOBAL ORDER
}

\author{
Francisco Martinez GrUZ*
}

\begin{abstract}
The right to self-determination has become an increasing legitimate demand of peoples seeking recognition and autonomy. In the beginning, this right was conceived in favor of peoples that depended on colonial powers, but today it has become a claim of any people that considers itself a people, as in the case of indigenous peoples or non-colonized peoples. This concept of the right to self-determination seems to be the path leading to a more heterogeneous world. Conversely, the rise of various problems that affect us globally seems to require the creation of international political institutions capable of solving these problems, which would most likely lead us toward a more homogeneous global order. Although both tendencies have powerful reasons that make them irreversible, it is not clear how they can co-exist. In this article, the author discusses whether a broad notion of the right to self-determination is compatible with three different models of global order proposed by Thomas Christiano, Rafael Domingo, and James Bohman, respectively.
\end{abstract}

KEYwords: Self-determination, external self-determination, internal selfdetermination, global order, global democracy, global community, statist global order, pluralist order.

RESUMEN: En la actualidad, el derecho a la autodeterminación se ha convertido en una demanda legítima creciente de los pueblos que buscan su reconocimiento y autonomía. Aunque este derecho inicialmente fue concebido a favor de los pueblos que dependían de las potencias coloniales, en la actualidad se ha vuelto una demanda de cualquier pueblo que simplemente se asuma como tal, como por ejemplo los pueblos indígenas o colectividades no colonizadas. Esta concepción del derecho a la autodeterminación parece conducirnos a un mundo más heterogéneo. En una dirección opuesta, el incremento de diversos problemas

MA in Political Philosophy, Universitat Pompeu Fabra de Barcelona; LL. B. Law School, UNAM. He is Law Professor at the UNAM Law School. E-mail: mtzcfrancisco@gmail.com; I am especially grateful to the two anonymous referees, and to Anisha Sankar and Sergio Tapia for their extremely valuable comments to earlier versions of this article. 
Esta revista forma parte del acervo de la Biblioteca Jurídica Virtual del Instituto de Investigaciones Jurídicas de la UNAM

que nos afectan globalmente parece requerir la creación de instituciones políticas internacionales con la capacidad para solventarlos. Esta necesidad parece conducirnos hacia el establecimiento de un orden global más homogéneo. Aunque ambas tendencias cuentan con poderosas razones que las vuelven irreversibles, no está claro cómo pueden armonizarse. En este artículo, el autor discute si una noción amplia del derecho a la autodeterminación puede ser compatible con tres diferentes modelos de orden global propuestos por Thomas Christiano, Rafael

Domingo y James Bohman.

Palabras Clave: Derecho a la autodeterminación, autodeterminación externa, autodeterminación interna, orden global, democracia global, comunidad global, orden global estatista, orden pluralista.

\section{Table of Contents}

I. INTRODUCTION

II. The Right to Self-Determination ................................................ 89

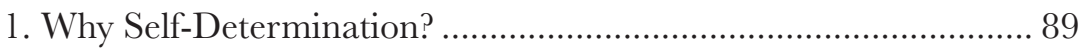

2. Self-Determination: External and Internal Self-Determination.... 90

3. Preliminary Comments on Self-determination and Global Orders ................................................................. 92

III. Three Models of Global Order..................................................... 94

1. Statist Global Order (Christiano) ............................................ 94

2. Global Community (Domingo)................................................ 96

3. Pluralist Order (Bohman)........................................................ 98

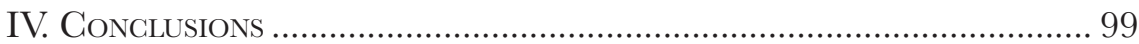

\section{INTRODUCTION}

In 2001, the Mexican Congress amended the Mexican Constitution to guarantee the right to self-determination for indigenous peoples. This constitutional reform was the result of a very intense movement claiming the rights of indigenous peoples triggered by the Zapatista Army of National Liberation (EZLN) years before. Parallel to these events, similar changes have taken place since then in the new constitution of Venezuela and in different municipal legislations in many Latin American States, such as Colombia, Ecuador, Bolivia, Nicaragua, Guatemala and Chile. ${ }^{1}$ The common denominator of all these cases consists in recognizing and vindicating the rights of indigenous

1 Stephen Allen, The UN Declaration on the Rights of Indigenous Peoples: Towards a Global Legal Order on Indigenous Rights? in TheOrising the Global Order, 187, 203 (Andrew Halpin \& Volker Roeben ed., . Hart Publishing 2009). 
peoples who have been historically oppressed and marginalized. Furthermore, on the basis of self-determination claims, there has been a central reaction against the pressures of both the neoliberal economy and assimilationisthomogeneous culture. ${ }^{2}$

However, indigenous peoples are not exclusively entitled to the right to self-determination. When the right to self-determination began to strengthen at the end of World War II (there had been an attempt for it to be considered a general norm in international law after World War I but it failed), ${ }^{3}$ it was conceived only in favor of peoples living in territories that were not self-governed, but depended on colonial powers. ${ }^{4}$ Self-determination was conceived as the right of those peoples to decide their political future. This does not mean, of course, that claims of peoples in favor of recognition, equality and independence are a recent phenomenon. Rather, they have been inherent to the formation of nation-States. ${ }^{5}$ Nonetheless, as soon as this right gained acceptance, though not without several obstacles, the number of subjects entitled to self-determination has increased to the extent of including, with some limits, indigenous peoples and non-colonized peoples. Catalonia and Crimea are very recent examples, but many scholars disagree that these peoples have such a right. Let us call the conception of the right whose holders are only colonized peoples restricted self-determination, and the conception of the right whose holders are both colonized and non-colonized peoples wide self-determination. Whatever view taken on this, it is not possible to deny today that wide self-determination is a powerful argument that seems to back and foster claims of growing minorities that seek recognition, autonomy or even secession. Perhaps, it will eventually prevail over restricted self-determination. If so, the world would increasingly become more heterogeneous than ever before. This does not necessarily mean that we will see a dramatic increase of multiple States, but there will at least be an increasing fragmentation of peoples into minorities due to their claims of recognition and self-determination. The difficulty of this scenario is that if States cannot deal with these claims, they will face the challenge of governing over these minorities.

2 François Houtart, Las autonomías multiculturales en el contexto de la globalización, in LA autodeterminación de los pueblos, 7, 15 (Juan Casañas ed., Icaria 2008).

3 Milena Sterio, The Right to Self-Determination under International Law: "Selfistans," Secession, and the Rule of the Great Powers, 10 (Routledge 2013).

4 In this article I use "colonial powers" and "colonial peoples" referring to "colonialism" as a practice of domination that involves the subjugation of one people to another. However, this political sense of the concept is not the only one and cannot be reduced to a simple definition. For a general view, I suggest reading Margaret Kohn \& Kavita Reddy, Colonialism, The Stanford Encyclopedia of Philosophy (Edward N. Zalta ed., Fall 2017), https://plato. stanford.edu/archives/fall2017/entries/colonialism/; and for a more in-depth analysis, see Pablo González Casanova, Colonialismo interno [una redefinición], LA TeOría MarXista Hoy. Problemas y Perspectivas 409-434 (Atilio A. Boron et al., CLACSO, 2006).

5 Rodolfo Stavenhagen, Conflictos étnicos y estado nacional, 7 (Siglo Veintiuno Editores, 2000). 
At the same time, and contrary to heterogeneity driven by the right to self-determination, there is a different and possible trend that seems to lead to a more homogeneous planet. As a result of the intense and relatively recent globalization, different problems and necessities concern all the peoples all over the world. These problems - such as economic crises, poverty, security, climate change, terrorism, war, the Internet and international trade regulations- need institutions, relationships and processes on a global scale that require the coordinated and joint action of all the countries since these problems cannot be solved by a single person, people or State. ${ }^{6}$ This is why scholars and politicians have been debating different proposals to delineate the contours of a global order that involves the integration of peoples, the inevitable vanishing of States' sovereignty, and the creation of institutions that can keep the global order. If this is the only way to deal with global threats, the new arrangement organizing both social life and world order is significant because the emerging institutions make decisions and impose rules that bind and affect distant individuals, communities and States across the world, whether these have agreed or not. Moreover, if minorities within States claim rights to self-determination and these rights are denied to them, it is likely that this would generate a conflict that would challenge the capacity of institutions to keep peaceful global order, especially if these minorities regard the global process as a threat.

Thus, both the right to self-determination and the need for global institutions aim at protecting important values and legitimate claims, as well as dealing with current problems. However, can the right to self-determination be compatible with the global order? In this article, I will demonstrate that although it would be desirable for both elements to be compatible, broad selfdetermination seems to be overturned and therefore impossible if analyzed under the light of the three influential models of global order discussed here. This does not mean that global order is necessarily against self-determination; but rather, if we imagine a global order in terms of these theories, it is possible that the right to self-determination can be overturned, or that our understanding of this right must change.

In order to do so, in the first section, I will describe the right to self-determination, highlighting its principal legal features according to international law. It is important to note that my starting point is a legal concept of the right to self-determination that is supposedly shared by the international community. Although I will mention the main philosophical and political arguments justifying it, my aim is not to further the debate, or to give a philosophical and historical explanation of this right. This will be a topic for later research.

6 See: Charlotte Ku. Taking stock: global governance in a post-Westphalian Order, in INTERNATIONAL Law, International Relations and Global Governance, 158 (Routledge 2012). Also: David Held \& Anthony McGrew. The Great Globalization Debate: An Introduction, in The GLobAL Transformations Reader, 1, 7 (David Held \& Anthony McGrew ed., Polity Press, 2003). 
In the second section, I will analyze this right in the light of three theories of global order, namely, the statist approach (Thomas Christiano), the global approach (Rafael Domingo) and the pluralist approach (James Bohman). I clarify some points regarding this selection. First, these theories are not the only ones that give an explanation of or delineate a global order, but I decided to choose them because each one presents a contrasting view from the other two, and because the homogeneity, which I regard as a trend that goes against the heterogeneity of self-determination, is clearer in these theories than in others. And second, the three theories share the same liberal roots, but do not deny the existence of other theories arising from different and valuable philosophical-political traditions, for instance, republicanism or critical perspectives. However, this article aims to open up broader research.

\section{The Right to Self-Determination}

In general terms, the right to self-determination can be understood as the right of peoples to freely determine their political status and to pursue their economic, social and cultural development. As we established below, I believe the broad concept of this right is problematic because of three important features related to the holders of self-determination, their relationship with the State, and the relation between the two components of self-determination (internal and external self-determination), as well as a possible global order. In order to understand this clearly, I will (a) address the justification of the right to self-determination; (b) explain wide self-determination and the two rights involved, and (c) lastly, comment on the aforementioned difficulties.

\section{Why Self-Determination?}

There are two kinds of arguments on which the right to self-determination is based..$^{7}$ The first one holds that membership to a cultural or historical people is important, not only because it shapes the identity of individuals, but it also makes their freedom possible. Our freedom requires individuals to be in a context where each one has options and acquires knowledge, and this can be fulfilled only if we rely on practices that are, by definition, social. ${ }^{8}$ It could be argued that this implies that individuals are irremediably linked to or determined by the community's identity or practices. However, this is not true. In fact, each person is able to shape and reshape his or her identity as much as he or she wants, but, as Young reasons, each person evolves his or

7 Iris M. Young, Inclusion and Democracy, 256 (Oxford University Press, 2000).

8 Peter Kraus, The politics of complex diversity: A European Perspective, 12 (1) Ethnicities, 3, 19 (2012). 
her identity in relation to cultural ties in a different way, and no one has the same attitude towards his or her community. This argument only points at the importance of the community in the initial shaping of both the self of individuals and their ability to exercise their freedom. Thus, individuals need the right to self-determination in order to preserve the sources of their selves and the means by which they become free people.

The second argument holds that structures of power, exploitation, and domination can be easily constructed in a context of social and cultural differentiation. On the basis of difference, peoples exclude others and take advantage of them. As a result, minorities are marginalized, exploited, oppressed, erased or assimilated by the larger majority. For this reason, the right to self-determination can be used as a shield to resist the threats perpetrated by the majorities. The Zapatist movement mentioned in the introduction of this article is an example of peoples who decided to confront the threats coming from both the State they belong to - oppression, discrimination, marginality - and international levels through, for instance, the economic charges imposed on them by international trade agreements.

Both arguments explain why legal efforts have been made in favor of the right to self-determination at an international level and have now become stronger. The right to self-determination has helped to bring to light the fact that current States are plurinational rather than the expression of a single homogeneous nation.

\section{Wide Self-Determination: External and Internal Self-Determination}

As noted above, the right to self-determination is the result of various efforts at an international level. It first came into being in the Charter of the United Nations (1945) immediately after World War II. However, its seeds can be found prior to that, guiding the remapping of Europe with the emergence of new States after the collapse of Austria-Hungary at the end of World War I. ${ }^{9}$ However, by virtue of the Charter, this right only "contemplated that member States should allow minority groups to self-govern as much as possible." 10 Greater progress in this was achieved decades later with the Declaration on the Granting of Independence to Colonial Countries and Peoples (1960), the UN International Covenant on Economic, Social, and Cultural Rights (1966), the UN International Covenant on Civil and Political Rights (1966) and finally the Declaration on Principles of International Law concerning Friendly Relations and Co-operation among States (1970). Based on these documents advocating the decolonizing movement in the world, many scholars and politicians have supported the idea that all groups, not only

\footnotetext{
9 Sterio, supra note 3.

10 Id.
} 
those that are colonies, ought to be entitled to self-determination (wide selfdetermination) ${ }^{11}$ Meanwhile, other scholars refute this extension (restricted self-determination).

I will not go deeper into this debate, but rather, I will assume the existence of a right to self-determination in its wider sense, the holders of which are both colonized and non-colonized peoples. This right, in turn, involves two rights, namely internal self-determination and external self-determination. ${ }^{12}$

According to internal self-determination, peoples can co-exist within a larger central State, but the State guarantees them the exercise of rights such as self-government, political autonomy, and cultural, religious and linguistic freedoms. Mainly, this is the right that has been defended for non-colonized peoples, specifically in plurinational contexts, and has gained acceptance at the international level. Furthermore, this is the kind of self-determination that is typically claimed for indigenous peoples and is the meaning given to the 2001 reform of the Mexican constitution. In this respect, all the international documents (International Legal Organization Convention 107 [1957] and 169 [1989], the UN Declaration on the Rights of Indigenous Peoples [2007], and more recently the American Declaration on the Rights of Indigenous Peoples [2016]) take into account the exercise of the right to self-determination by indigenous peoples within existing States without the possibility of secession and becoming a new State.

Regarding external self-determination, peoples are entitled to separate from their mother States in order to achieve self-government, to determine their own political status, and to be free of alien domination. This right to secession has only applied exclusively to colonial peoples, keeping in mind that, according to a restrictive interpretation of self-determination, once the peoples became independent, such a right expired. Consequently, after one people become independent, it would not be acceptable for a group within it to claim its right to secession and therefore, become independent. However, given that now there is a growing opinion that this right should be recognized for non-colonized peoples as well under particular conditions, it seems that the right to external self-determination remains latent whenever peoples

11 An accurate and brief summary of the features of each document concerning the right to self-determination can be found in Milena Sterio's book which is quoted throughout this article.

12 Abdulqawi A. Yusuf argues that there is also a third normative strand of the right that has to do with the peoples' right to freely pursue their economic, social, and cultural development, i.e. socio-economic self-determination. However, I will not include this interesting vein since the purpose of this section is to present the general concept of the right to self-determination, which will allow me to analyze it in the light of certain theories of global order. Abdulqawi A. Yusuf, The role that equal rights and self-determination of peoples can play in the current world community, in Realizing Utopia. The Future of International Law, 375,391 (Antonio Cassese, Oxford 2012). In addressing internal and external self-determination, I will mainly use Milena Sterio's analysis. Supra note 3, at 18-22. 
decide to exercise it. ${ }^{13}$ Actually, there are several examples of non-colonized peoples that, contrary to the restricted interpretation, have asserted the right to external self-determination, such as those in the Aaland Islands, Kosovo, or more recently, Crimea (although in this case, it has yet to be internationally recognized). What is more, in different countries, this right is guaranteed in their own legal systems, as in the cases of Ethiopia and Saint Kitts and Nevis, whose constitutions have a secession clause.

Thus, regardless of the different arguments that deny the existence of a right to external self-determination inherent to peoples, the wide version of self-determination implies that all peoples -whether colonized or not- are inherently entitled to this right. This means that, whenever they so desire, they are entitled to exercise internal or external self-determination.

\section{Preliminary Comments on Self-Determination and Global Orders}

Before analyzing models of global order, I will make some preliminary comments on three problems of self-determination that cannot be overlooked.

First, since self-determination is a collective right, the subject entitled to this right is the people, but it has not been clear how to define what a people is. This is important since it allow us to recognize the holder of such a right. ${ }^{14}$ Internationally, for example, it has been said that for a group to be a people, it must meet both objective and subjective requirements. ${ }^{15}$ The former consists of sharing common characteristics such as language, religion, history, cultural heritage and territorial integrity. The latter requires that they must perceive themselves as a distinct 'people'. Let us focus on territorial integrity. Territory is frequently a main element used to define the existence of a people, but it is problematic since wars, economic crises, and all the consequences of globalization cause peoples to abandon their own territory and relocate to another, or disperse to different several countries. This fact can produce the assimilation of those peoples into the people of the State where they migrate and can erase individuals' cultural ties. But if individuals do not assimilate, they form

13 An interesting analysis of the theories that explain when a people is entitled to external self-determination, although applied to Catalonia, is Ferran Requejo \& Marc Sanjaume, Recognition and Political Accommodation: from Regionalism to Secessionism-The Catalan Case, in Recognition and Redistribution in Multinational Federations, 107,132 (Grégoire, J.-F. and Jewkes, M., eds., Leuven 2015).

14 Alain Badiou explains the different ways in which "people" is used and the difficulties each implies. According to him, there are two negative senses of the word "people". The first one relates to racial or national identity, and this violently brings a despotic State into existence. The second subordinates the recognition of a "people" to a State that is assumed to be legitimate. See Alain Badiou, Twenty-four notes on the uses of the Word "people", in WHAT IS A People?, 21, 31 (Jody Gladding trans., Columbia University, 2016).

15 Sterio, supra note 3 , at 16. 
minorities without any rights, much less the self-determination that guarantees their own identity. Thus, for example, it would be very doubtful that if a people were forced to abandon their own territory because of economic crises or wars originated by external actors (as is common today), the lack of territory would be enough to deny these people any right to self-determination.

Second, and related to the previous issue, since the subject of this right is a people, it means that a people are not necessarily confined to the boundaries of a State. This can trigger the emergence of distinct groups within a State claiming the right to self-determination. At least three different groups in a State can claim this right: 1) indigenous peoples, 2) non-indigenous peoples, but members of the same State, and 3) migrants. If they are indigenous peoples, their right to self-determination can be recognized. This has been the case in different Latin American countries, particularly Mexico, whose constitution defines the country as a pluricultural nation, originally based on indigenous peoples who preserve their own social, economic, cultural and political institutions. However, in these cases, self-determination is recognized in terms of the State where the peoples live and not in terms of peoples who are seeking recognition. To put it differently, the dominant group regarded as the legitimate people is the one that defines the sense in which marginalized groups can exercise the right to self-determination. If those groups are not indigenous but are members of the same State, any claim to self-determination can be refused. The example of Catalonia in Spain or Quebec in Canada sheds light on this respect. Finally, in the third case, migrant people can become a minority within States but without any right to either representation or self-determination. It should be noted that in these three different cases, the common factor is cultural ties. Nonetheless, it would be interesting to think that the process of globalization and the development of telecommunications could open new scenarios where individuals without cultural ties could voluntarily shape a people. It might even be the case of distant individuals around the world who decide to become a people, as some cosmopolitan proposals maintain.

The third problem is that since self-determination fosters heterogeneity in a world society, it is not clear to what extent its two components -internal and external self-determination - are compatible with global institutions or global governments. Each component raises its own problems. On the one hand, for example, by virtue of internal self-determination, a people could choose an autocratic government, but if it had to participate in creating global institutions, the rest of the peoples - let us suppose they are not autocracies but democracies - would be at a disadvantage since autocrats do not have to take into account the people's opinion to make a decision, whilst democratic governors have to do so. And this relation would be unfair. ${ }^{16}$ As a result, in

16 Thomas Christiano. Self-Determination and the Human Right to Democracy (March 25, 2017) (unpublished manuscript). 
order to have legitimate institutions, autocracies would have to become democracies. Nonetheless, I doubt whether this conclusion is truly compatible with the right to govern itself without outside interference since it would seem that the right to self-determination is conditioned to a democratic form of government, a condition imposed from outside. To put it differently, if global institutions require peoples to decide to be democracies, I do not think this is a free choice made by virtue of the right to self-determination. On the other hand, with external self-determination, it might develop into a global order in which peoples may not leave the political order without burdensome costs. This is not too far from reality since the global economy, for example, is something that affects all peoples and they cannot escape from it.

Thus, bearing in mind the twofold character of self-determination and the three problems that I briefly discussed, the next section will analyze three different models of global order and whether self-determination is compatible with each of them.

\section{Three Models of Global Order}

In recent decades, there have been different proposals on global order dealing with global problems and the growing trend to create supranational institutions classified under various taxonomical divisions. In this article, I will only consider three specific theories that can be identified as statist, plural and global. These theories envisage a minimum (statist theory), medium (plural theory) or maximum (global community theory) design of global order. After presenting each theory, I will analyze each one in terms of self-determination, i.e. the people, and both internal and external self-determination.

\section{Statist Global Order (Christiano)}

In general terms, this view maintains that international institutions are important in the global order to keep peace between States, as well as to safeguard democracy, deliberation and human rights. Nevertheless, in creating international institutions, democratic States are the main players since they are the main vehicles of accountability of political power. ${ }^{17}$ Christiano argues that this kind of global order is the result of a fair and voluntary association of States, based on the idea that international law and institutions are created as long as States give their consent during the treaty-making process. How-

17 Thomas Christiano, Is Democratic Legitimacy Possible for International Institutions? in GLOBAL Democracy: Normative and Empirical Perspectives, 69, 70 (Archibugi, Daniele et al. eds., Cambridge University Press 2012); Jonathan Kuyper, Global Democracy in The StanforD EnCyClopedia OF Philosophy, http://plato.stanford.edu/archives/spr2016/entries/globaldemocracy/ (May 15, 2016). 
ever, he argues, it is necessary to complement this model with the relevance of individuals at an international level. Thus, by creating global institutions, two requirements must be fulfilled: first, States must be robustly democratic, giving adequate protection and representation to minorities; and second, treaties must be fairly negotiated among States. ${ }^{18}$

Considering this, the right to self-determination in Christiano's version is very restrictive (Christiano 2013) ${ }^{19}$ First, this right belongs to a community that is a well-defined group with jurisdiction over a specific territory. It should be noted that Christiano is only thinking of peoples whose boundaries correspond to those of their States. Thus, for example, peoples who are forced to migrate or a group of individuals that belong to a State but decided to become independent, are not entitled to this right.

Second, since his model of global order requires peoples to be democratic, it would seem that internal self-determination would not allow peoples to choose their own government freely because it has to be a democratic one. If so, it seems that internal self-determination is not properly a right. To overcome this problem, Christiano reasons that self-determination stems from a human right to democracy. ${ }^{20}$ To put it differently, a people have full rights to self-determination when its members' human right to democracy is fulfilled. Thus, by virtue of self-determination, a people could become an autocracy or any other kind of government different other than democracy provided that all the individuals unanimously decide to choose such a government. Nonetheless, the problem remains since even if a people becomes an autocracy through this process, at international level it is required that peoples be robustly democratic. In addition, as Christiano suggests, if self-determination were respected and peoples freely choose their government, it might be the case of an autocratic State having to participate in creating global institutions. In these circumstances the other peoples - that are not autocracies but democracies - would be at a disadvantage since an autocrat does not have to consult his decision with his people whilst democratic governors would have to do so; and this relation would be unfair. In those cases, Christiano solves the problem by arguing that whenever an international institution is created, non-democratic peoples need to be organized democratically to participate in that process. The problem is that this solution is unrealistic, but beyond this, I think the basis on which Christiano builds his arguments is not convincing. According to him, self-determination derives from the right to democracy and not vice versa. Nonetheless, if democracy is understood as a kind of

18 These two requirements constitute a standard of legitimacy. However, Christiano argues that it leads us to an impasse since in order to bring it about, it calls for democratic deliberation and decision making without the possibility of global democratic institutions to guarantee such a process. See Christiano, supra note 18, at 79-92.

19 Christiano, supra note 17.

20 Id. at 22. 
government, individuals should have the right to choose such a government; and thus, they have to have the right to self-determination. Christiano would perhaps contend that in order to respect that right, each person would need to participate in minimal egalitarian democratic circumstances, which is why he argues that prior to self-determination, individuals are entitled to the right to democracy. However, I would answer that this right cannot be considered a right to democracy, but to participation. If so, internal self-determination can be preserved.

Finally, in Christiano's explanation of global order, external self-determination seems to be protected as long as the respective peoples participate voluntarily and equally in the creation of international institutions. In this way, peoples participate whenever they decide to do so. The problem with this concept is that it does not consider the fact that there are international institutions that necessarily come in to being and peoples cannot reject them without facing burdensome costs. Thus, in those circumstances, external selfdetermination cannot be guaranteed. Moreover, alien domination could not be avoided in treaties in which one party takes advantage of the other, since treaties would be negotiated fairly in order to prevent a situation of this kind. So, it would be necessary to have institutions that, as Christiano recognizes, do not yet exist.

\section{Global Community (Domingo)}

To deal with the problems of globalization, this model tries to be more democratic by creating a system which protects human rights, and providing it with democratic mechanisms for citizen input at the global level. ${ }^{21}$ Archibugi, for example, argues that we should move towards a "cosmopolitan democracy", which consists of the simultaneous development of democracy at different levels of governance that are mutually autonomous but complementary. ${ }^{22}$ Nevertheless, there is a more radical proposal that I address here. Domingo holds that the current international society, which is basically composed of States, should give way to a 'global community' that emphasizes the person as its main subject, and fosters unity while avoiding homogeneity. ${ }^{23}$ The global community would be formed by persons, peoples, political organizations, and so on. He argues that the global order does not attempt to eliminate local, national, or supranational orders; rather, it seeks to harmonize them although Domingo does not cast out the elimination of nation-states as a long-term goal. Additionally, he proposes the creation of the United Hu-

\footnotetext{
21 Kuyper, supra note 17.

22 Daniele Archibugi, The Global Gommonwealth of Gitizens: Towards Cosmopolitan Democracy, 97 (Princeton University Press 2008).

23 Rafael Domingo, The New Global Law, 102 (Cambridge University Press 2010).
} 
manity with a Global Parliament whose decisions would be legally binding and judicially controllable. ${ }^{24}$

Domingo argues that self-determination has traditionally been linked to peoples that correspond to States or nation-states and, therefore, such a right is based on sovereignty. By virtue of this right, each State determines or sets its own limits. As Domingo says, Kelsen considered that sovereignty was supreme, independent, and capable of limiting itself by means of legal order. ${ }^{25}$ Nonetheless, if we held this notion of sovereignty and self-determination today, it would be impossible to make them compatible with new forms of organization congruent with globalization. ${ }^{26}$ For that reason, he concludes, the universality of globalization, and the order he proposes, is incompatible with sovereignty. I should add that this implies incompatibility with self-determination, as well. He argues that self-determination is not necessarily equivalent to the right to be totally independent without any interference. If we decided to maintain this correspondence, the result would be the dichotomy of dependence/independence, and this is erroneous since in today's world, all communities are dependent or at least interdependent, but never truly independent. ${ }^{27}$ Instead, self-determination means self-government and in this way peoples can establish their own legal order and both develop a specific cultural, social and economic region, and be recognized by the international order.

Notice that in this explanation, self-determination is a right which peoples are entitled to regardless of whether they correspond to States or to peoples who exercise jurisdiction over a clearly defined territory. I conclude this since Domingo calls into question the territoriality that is frequently attached to self-determination. But if so, he does not explain how self-determination can be achieved by peoples in those circumstances. In addition, he neither provides any criteria to identify what a people is.

As to internal self-determination, it seems to be protected since Domingo holds that self-determination must be understood as self-government. However, what might happen if there were peoples whose governments were not democracies or were not strongly committed to human rights? Apparently, if the global government ordered local governments to reform in order to be more democratic or to respect human rights, peoples would be compelled to comply with that order since the decisions of global government would be binding. In this case, as in Christiano's theory, internal self-determination is restricted to certain polity, and I have already commented why this seems to contradict self-determination.

\footnotetext{
24 Id. at 146.

25 Id. at 70.

26 Id. at 71.

27 Id. at 87
} 
With regard to external self-determination, although Domingo points out that self-determination cannot be understood as independence since today all peoples are at least interdependent, it seems that there is a room to think that peoples can avoid alien domination in a global order. Domingo maintains that the global community avoids homogeneity because he sees it as made up of individuals, peoples and organizations. Nevertheless, it is not clear how homogeneity and alien domination can be avoided. If there is a global community called United Humanity, whose main organ is a Global Parliament, which entities would be represented? It would seem that the deputies would be representatives of individuals, peoples, political organizations and so on. If so, it would be unfair that the vote of one people's representative had the same weight as a representative of a political organization or a group of individuals that does not constitute a people. ${ }^{28}$ Thus, without these clarifications in Domingo's approach, external self-determination is undermined.

\section{Pluralist Order (Bohman)}

One model that is half-way between the statist and the global model is the pluralist order. According to Bohman, in current circumstances of politics and justice, there are three experimental trends that lead us to different scenarios. The first one is economic and neo-liberal, which leads us to opening the borders to a world market. Although this can produce the greatest wellbeing, it is not democratic. The second one proposes closed political communities since it emphasizes the vulnerability of communities and therefore, stresses their right to self-determination as a means to protect them. However, at least explicitly, this description does not take into account the individuals who do not belong to any community or who are immigrant peoples. The third one, which is the one he favors, is a transnational democracy that "provides a basis on which we can reconceive democracy in a complex, pluralized and globalized context." ${ }^{.9}$ Let us see more in point in more detail.

Bohman argues that in order to deal with global problems, we need international institutions, but these must be the result of democratic conditions. This is linked to the republican principle of non-domination, which deals with both non-domination of individuals, and non-domination resulting from collective decisions. Thus, in an interdependent world and in order to avoid domination, individuals should have the power to influence problematic interdependencies. This democratic minimum is a minimum of powers, the necessary conditions needed for democratization that allow all those af-

28 Habermas, for example, proposes a "transnational democracy" whose principal organs are two chambers, one representing individuals and the other, States. Jürgen Habermas. The Lure of Technocracy, (Polity Press 2015).

29 James Bohman. From Self-Legislation to Self-Determination: Democracy and the New Circumstances of Global Politics in 17(1) Critical Horizons, 123, 133 (2016). 
fected to be able to form and change the terms of their common life. In this way, self-determination is understood as non-domination.

It is interesting to note that the subject of self-determination is not the people or the citizens whose borders are aligned with the geographical territories of States. Rather, it belongs "to everyone equally in any situation with the potential of domination". ${ }^{30}$ This makes interactions possible among multiple and overlapping demoi. One interesting implication of this argument is that peoples within States would no longer have to participate in making treaties or creating international institutions through their own States; rather, they would do so by themselves. Nevertheless, Bohman does not explain how this participation of multiple demoi could be effected. In addition, since selfdetermination becomes an individual right, we could ask to what extent the ties of the community or the people weaken or are dissolved.

With regard to internal self-determination, this concept does not accept that peoples may choose the polity of their preference. Since domination is at stake, all individuals should be entitled to participate in decision-making, and this can be achieved only if the polity is committed to democracy. Thus, peoples should be democracies. Again, self-determination is not as free as we would suppose.

In relation to external self-determination, it seems it is true that peoples would be free from alien domination. However, it might be the case in which there were different peoples insisting on participating in the decision-making that concerns them because there is a specific common problem. In this context, could we accept a burden to be imposed on certain people as a result of the decision of a majority? If the answer is yes, then it is obvious that alien domination would not be avoided. If the answer is no, international institutions would be needed to control the process of deliberation, and as Christiano says, such institutions do not exist. Nonetheless, Bohman does not provide a satisfactory solution.

\section{Conclusions}

In this article I have argued that self-determination has had a great importance because it is mainly based on two arguments: first, that this right protects the community, which is important in shaping both the self of individuals and the ability to exercise their freedom; and second, that it is a safeguard to resist the threats of structures of power, exploitation and domination perpetrated by powerful peoples or majorities within the same State. Further, I have mentioned that as a right, in terms of international law, it involves two rights, namely, internal and external self-determination. According to international law, not all the peoples are entitled to both rights. In order to

$30 \quad I d$. 
maintain the stability of States, only those peoples who are oppressed by a larger number of people within the State they belong to can claim external self-determination. But I have assumed a broad notion of self-determination in which a people do not need to be oppressed to be entitled to both internal and external self-determination. This assumption is not arbitrary; it is a fact that nowadays even peoples belonging to traditional democracies are claiming the right to secession that international law only recognizes for colonial peoples.

I have also mentioned that in taking into account globalization, global problems and the unavoidable integration of the world, the homogeneity of a 'global order' is a trend that will apparently not change. Thus, I have explained three theories of global order that suggest three different scenarios of the political configuration of the world. After analyzing them, I have stated that everyone holds the right to self-determination I endorse. The three theories imply a new version of self-determination that tries to make it compatible with global order. It is important to note that something all of them have in common is their commitment to democracy. This is why even the statist theory - that seems to respect the free will of each people to determine their political regime - restricts self-determination to democracy. Moreover, it is worth mentioning that only the pluralist theory includes a new concept of the subject of self-determination: whilst Christiano and Domingo consider peoples holders of self-determination, Bohman argues that it instead belongs to individuals who are under conditions of potential domination, and this would imply a change in the boundaries of the people depending on each case.

Nonetheless, I am not convinced by these theories and I would not be willing to accept their explanations of the right to self-determination. I am aware that what I have discussed here is not enough to reach final conclusions on this topic, but let me present some important notes:

1. The right to self-determination outlined in these theories diverges from the concept that has been historically developed by peoples. It seems that if we hypothetically accepted the new scenario proposed by each theory, we would have to change this concept. But accepting changes would also imply eliminating important elements of this right. In other words, this would mean erasing the long battles through which peoples have won rights to protect the values they consider worthy. One of these elements is the holder of self-determination. In my opinion, it is a collective subject, a group of individuals, and not an individual without any ties to a community. As I explained at the beginning, collectivity is valuable not because it is a sum of individuals, but because individuals only form their selves and become free individuals within a community. This is one of the reasons for self-determination.

2. Another element to examine is the concept of "people" as the holder of self-determination. Migrations, new technologies, climate change and the natural gregarious disposition of human beings should lead us to 
consider that the formation of peoples is a constant process. If so, it is not understandable why self-determination must be restricted to existing peoples. Simply bear in mind that a restricted concept could hide the domination of existing peoples over new ones.

3. More challenging is to note that since its inception, the right to selfdetermination was tied to the State in two ways. First, it depends on States' capacity to respect this right, like any other right. But in a global community, it would require the capacity of global institutions for the same purpose. If it is now very common to hear news about the violation of the rights of indigenous peoples caused by actions or omissions of current States, it is not clear why international institutions would be better in respecting the rights of all the peoples in the world. Second, self-determination was conceived as an aspiration of oppressed peoples to become independent States. However, if the tendency towards the disappearance of States is true, we should rethink self-determination as a claim that does not imply becoming a State. In this case, it would be very interesting to look at the experience of indigenous peoples and how they organize their lives within the structure of existing States. Moreover, this would give us a different example of how these groups conceive their own self-determination and would probably shed light on a new form of this right in an interconnected world with vanishing States.

I recognize that wide self-determination is very demanding considering the prevailing trend of self-determination at the international level, but it is useful to become aware of the difficulties involved if it continues gaining acceptance. If self-determination is limited in the light of these theories and if this is a common characteristic of all global theories, it is therefore necessary to outline a concept of self-determination that is compatible with a global order, and does not obliterate its meaning as a right to protect the freedom of individuals from forms of domination. 